\title{
Saxitoxin exposure in an endangered fish: association of a shortnose sturgeon mortality event with a harmful algal bloom
}

\author{
Spencer E. Fire ${ }^{1, *}$, Jessica Pruden $^{2}$, Darcie Couture ${ }^{3}$, Zhihong Wang ${ }^{1}$, \\ Marie-Yasmine Dechraoui Bottein ${ }^{1}$, Bennie L. Haynes ${ }^{1}$, Trey Knott ${ }^{1}$, \\ Deborah Bouchard ${ }^{4}$, Anne Lichtenwalner ${ }^{4}$, Gail Wippelhauser ${ }^{5}$
}

\author{
${ }^{1}$ Marine Biotoxins Program, NOAA Center for Coastal Environmental Health and Biomolecular Research, Charleston, \\ South Carolina 29412, USA \\ ${ }^{2}$ Northeast Region Shortnose Sturgeon Recovery Program, NOAA National Marine Fisheries Service, Gloucester, \\ Massachusetts 01930, USA \\ ${ }^{3}$ Marine Biotoxin Monitoring Program, Maine Dept. of Marine Resources, West Boothbay Harbor, Maine 04575, USA \\ ${ }^{4}$ University of Maine Animal Health Laboratory, Dept. of Animal and Veterinary Science/Cooperative Extension, Orono, \\ Maine 04469, USA \\ ${ }^{5}$ Bureau of Sea-Run Fisheries and Habitat, Maine Dept. of Marine Resources, Augusta, Maine 04333, USA
}

\begin{abstract}
Saxitoxin (STX)-producing blooms of the toxic dinoflagellate genus Alexandrium have been responsible for devastating ecosystem-wide impacts in coastal waters of the northeastern USA. In the summer of 2009, a severe Alexandrium bloom in New England coastal waters cooccurred with a shortnose sturgeon Acipenser brevirostrum mortality event in Sagadahoc Bay, Maine, USA. Thirteen individuals of this endangered fish species were found dead on 10 July 2009, and this die-off was associated with extremely high Alexandrium cell densities, recordbreaking toxin burdens (>80 $000 \mathrm{ng} \mathrm{g}^{-1}$ ) in shellfish, and closures of shellfish beds affecting nearly the entire Maine coastline. STX-like activity was detected in sturgeon $(\mathrm{n}=3)$ stomach contents and liver and gill tissues via neuroblastoma assay and receptor-binding assay at concentrations ranging between 37 and $2300 \mathrm{ng}$ STX-eq. $\mathrm{g}^{-1}$ (STX equivalents per gram sample). Stomach content analyses of the 3 necropsied sturgeon carcasses showed a large number of amethyst gem clams Gemma gemma. Liquid chromatography-mass spectrometry confirmed the presence of STX and related congeners in sturgeon stomach contents, at concentrations between 311 and $743 \mathrm{ng} \mathrm{g}^{-1}$. The present study marks the first reported detection of STXs in shortnose sturgeon, and provides evidence of trophic transfer of Alexandrium toxins as a potential cause of mortality in this event, as well as a threat to the health of this endangered population of fish.
\end{abstract}

KEY WORDS: Saxitoxin - Sturgeon - Harmful algal bloom - Paralytic shellfish toxin · HAB · Acipenser brevirostrum · Maine

\section{INTRODUCTION}

Harmful algal blooms (HABs) are known globally for their devastating impacts on aquatic organisms, coastal economies and human health, primarily as a result of exposure to biotoxins produced by toxic marine phytoplankton (Hoagland et al. 2002, Landsberg 2002, Kirkpatrick et al. 2004). Several classes of $\mathrm{HAB}$ toxins have been identified as contributing factors in large-scale mortalities of marine wildlife 
and are responsible for various shellfish poisoning syndromes in humans (Van Dolah 2000, 2005, Landsberg 2002). In coastal waters of the northeastern USA, blooms of the toxic dinoflagellate genus Alexandrium cause frequent, severe HABs, and have been the cause of recurrent shellfish harvesting closures, as well as marine mammal, seabird and finfish mortalities (Sasner et al. 1975, White 1980, Anderson \& White 1989, 1992, Geraci et al. 1989, Anderson 1997). Alexandrium blooms produce a suite of related toxic compounds known as saxitoxins (STX), which are responsible for the human illness known as paralytic shellfish poisoning (PSP) when associated with consumption of contaminated bivalve shellfish. These compounds are highly neurotoxic, with a toxic potency 100-fold greater than sodium cyanide (Deeds et al. 2008). Like other HAB toxins, the negative effects of STXs on coastal ecosystems are primarily manifest through consumption of toxic plankton by filter-feeding aquatic organisms such as bivalves (e.g. mussels, clams) or small, schooling planktivorous fish (e.g. herring, mackerel), which can then act as toxin vectors to higher trophic levels and have devastating ecological impacts (Van Dolah 2000). Among the more salient impacts of STX exposure on coastal wildlife is its potential role in the decline of endangered species such as the North Atlantic right whale Eubalaena glacialis population inhabiting the Bay of Fundy and adjacent New England waters (Durbin et al. 2002, Doucette et al. 2006a).

This HAB-impacted region of the northeastern USA is also home to the shortnose sturgeon Acipenser brevirostrum. The shortnose sturgeon is a large anadromous fish that inhabits large coastal rivers, estuaries, bays, and marine waters ranging from New Brunswick, Canada, to the St. Johns River of Florida. Shortnose sturgeon are currently listed as an endangered species throughout this range under the Endangered Species Act of 1973, as amended (Udall 1967). The principal threats to this species' survival include pollutant discharge, habitat loss, or degradation due to channel dredging, bridge and dam construction, and mortality due to dredging, bycatch and other human interaction (NMFS 1998). Shortnose sturgeon are a long-lived (30 to $40 \mathrm{yr}$ ) benthic fish mainly occupying the deep channel sections of large rivers and known to feed primarily on benthic invertebrates. Major prey items of adult shortnose sturgeon typically include gastropods, polychaetes, small benthic fishes, and small bivalves, including species known for accumulating high levels of STXs during toxic Alexandrium blooms (McCleave et al. 1977, Dadswell et al. 1984, Moser \&
Ross 1995, Kynard et al. 2000, Collins et al. 2002, Bricelj et al. 2005). Thus, in addition to the various known threats to shortnose sturgeon survival, their feeding habits and proximity to frequent HABs present a potential emerging threat to this species due to exposure to natural toxins.

On 10 July 2009, a sturgeon mortality event occurred in coastal waters of Maine. During the course of this mortality event, 13 shortnose sturgeon and 1 Atlantic sturgeon Acipenser oxyrinchus were found dead in Sagadahoc Bay, in the Kennebec River. This mortality event occurred simultaneously with a toxic Alexandrium bloom, the impacts from which are thought to be the most severe on record for this region (D. Couture unpubl. data). In fact, during the period of the sturgeon mortalities, $95 \%$ of shellfish beds in Maine were closed to harvest for human consumption due to high concentrations of STXs, resulting in a fishery failure and receipt of NOAA disaster relief funds to affected stakeholders (Couture 2009). Here we present data confirming the presence of STXs in samples collected from several shortnose sturgeon carcasses recovered during this mortality event, and discuss the implications of HAB toxin exposure in this endangered species. We also present associated environmental data describing the extent and severity of the co-occurring Alexandrium bloom and its toxic impacts on shellfish resources in the study region. The present study highlights the need for increased effort to investigate HAB impacts on already threatened populations of finfish and to understand HABs as an emerging health stressor in regions where toxin-producing algal blooms are a common occurrence.

\section{MATERIALS AND METHODS}

\section{Fish sample collections}

On 10 July 2009, 13 shortnose sturgeon Acipenser brevirostrum and 1 Atlantic sturgeon A. oxyrinchus carcass were discovered by the authors in Sagadahoc Bay, near the mouth of the Kennebec River, Maine, USA $\left(43.766^{\circ} \mathrm{N}, 69.758^{\circ} \mathrm{W}\right)$. Three of the shortnose sturgeon carcasses were collected by the authors and frozen for subsequent necropsy, sampling, and analysis; all other carcasses were buried due to the advanced state of decomposition. Body mass $(\mathrm{kg})$ and body length (fork length [FL] and total length; $\mathrm{cm}$ ) were recorded for each animal. Full necropsies of the 3 recovered carcasses were performed, and samples of stomach contents and gill and liver tissue were col- 
lected for subsequent biotoxin analysis. Samples were bagged separately and kept frozen at $-20^{\circ} \mathrm{C}$ until toxin extraction.

\section{Shellfish toxin datasets}

Data for saxitoxins in commercial shellfish are collected as part of ongoing state-wide biomonitoring efforts performed routinely by the Maine Dept. of Marine Resources. Over 270 sampling sites distributed along $5500 \mathrm{~km}$ of coastline were used to collect various species of bivalve shellfish and crustaceans. These stations are sampled on a weekly basis prior, during, and following the red tide season (typically spring to summer), although sampling may extend throughout the year. Shellfish samples are analyzed for PSP toxins using the standard mouse bioassay, and collection and toxin analytical methods followed those described in Couture (2007). Toxin data included in the present study are from samples $(\mathrm{n}=4113)$ collected between 27 February and 8 December 2009. Blue mussels Mytilus edulis were collected at all primary stations and represent the majority of samples collected $(\sim 70 \%$; $n=2831)$. Several other additional marine invertebrate species were also collected during the peak of the red tide season, including softshell clams Mya arenaria ( $\mathrm{n}=870)$, Atlantic surf clams Spisula solidissima $(\mathrm{n}=32)$, razor clams Ensis directus (data not shown), bay quahogs Mercenaria mercenaria (data not shown), eastern oysters Crassostrea virginica (data not shown), amethyst gem clams Gemma gemma ( $\mathrm{n}=1)$, American lobster Homarus americanus ( $\mathrm{n}=120)$, horse mussels Modiolus sp. $(\mathrm{n}=$ 42), ocean quahogs Arctica islandica ( $\mathrm{n}=195)$, and European oysters Ostrea edulis (data not shown).

\section{Saxitoxin extractions from sturgeon}

Samples of sturgeon liver, gill, and stomach contents were extracted by combining 1 to $2 \mathrm{~g}$ of sample with an equal volume of $0.1 \mathrm{~N}$ hydrochloric acid, homogenizing using a handheld tissue homogenizer, and sonicating for 2 min using a Branson 450 probe sonicator (Branson Ultrasonics Corp.) at $30 \%$ power. The $\mathrm{pH}$ of the resulting homogenate was measured and adjusted to fall between 3.0 and 4.0. Homogenized samples were boiled for $5 \mathrm{~min}$, allowed to cool to room temperature, and centrifuged for $10 \mathrm{~min}$ at $3400 \times g$. The supernatants were collected and filtered through $0.2 \mu \mathrm{m}$ hydrophilic polypropylene (GHP/GxF) syringe-driven filter discs (Acrodisc; Pall
Life Sciences). Sample extracts were further cleaned using Sep-Pack Light C18 cartridges (Waters Corporation) prior to analysis. Extracts were stored in glass vials at $4^{\circ} \mathrm{C}$ until analysis.

\section{Receptor binding assay analysis}

Sample extracts were analyzed for STX-like activity using a receptor binding assay (RBA) developed for PSP toxins, utilizing microplate format methods outlined by Doucette et al. (1997) and Van Dolah et al. (in press). Briefly, the RBA measures competition between radiolabeled STX and any STX present in samples for binding to voltage-gated sodium channels in rat brain synaptosomes, the pharmacological target of STX. Used in conjunction with a calibration curve using FDA standard STX reference material (S. Hall, United States Food and Drug Administration/ Centre for Food Safety and Applied Nutrition, Washington, DC), this functional assay quantifies STXs based on their binding affinity for a specific cell membrane receptor, in effect estimating the total toxic potency of a sample. Since the endpoint of this functional assay is the composite toxicity for all receptor-bound STX congeners, concentrations are therefore reported as nanograms of STX equivalents per gram of sample (ng STX-eq. $\mathrm{g}^{-1}$ ). Sample extracts were diluted prior to analysis to eliminate interference in the assay due to non-specific binding of toxin and other matrix effects. The detection limit of this method was $31 \mathrm{ng}$ STX-eq. $\mathrm{g}^{-1}$.

\section{Neuroblastoma cytotoxicity assay analysis}

Sample extracts were further tested for STX-like activity using the neuroblastoma (N2A) cytotoxicity assay following the methods described by Manger et al. (1993), with minor modifications (Dechraoui et al. 2007). In this functional assay, STX sodium-dependent toxic activity was measured by the decreased viability of neuroblastoma cells treated with ouabain, veratridine, and brevetoxin. Mouse neuroblastoma cells (N2A, American Type Culture Collection, Manassas, Virginia) were grown at $37^{\circ} \mathrm{C}$ in a humidified atmosphere containing $5 \% \mathrm{CO}_{2}$ in Roswell Park Memorial Institute culture medium supplemented with $10 \%$ fetal bovine serum and $1 \mathrm{mM}$ sodium pyruvate. Cells were added to a 96 -well culture plate $(3 \times$ $10^{4}$ cells in $100 \mu \mathrm{l}$, per well). After $24 \mathrm{~h}$ incubation in the 96-well plate, each well was treated with various dilutions of the sample extract with and without 
the presence of ouabain $(0.5 \mathrm{mM})$, veratridine (0.05 mM), and brevetoxin (1 nM). Cell viability was measured after 18 to $24 \mathrm{~h}$ incubation using MTT tetrazolium salt, (3-(4,5-Dimethylthiazol-2-yl)-2,5diphenyltetrazolium bromide) with the absorbance of the formazan product measured at $544 \mathrm{~nm}$ using a FLUOstar microplate-based plate reader (BMG Labtech). The limit of detection of this method is approximately $20 \mathrm{ng}$ STX-eq. $\mathrm{g}^{-1}$.

\section{LC-MS analysis}

Selected sample extracts testing positive by RBA and/or N2A methods were subsequently analyzed by liquid chromatography-mass spectrometry (LC-MS) for confirmation of STX and related PSP congeners. This analytical method separates and analyzes ionized STX based on known mass/charge ratios $(\mathrm{m} / \mathrm{z})$, and allows for confirmation of individual toxin congeners using certified reference standards. Analyses were performed using an Agilent LC 1100 coupled to an AB SCIEX 4000 QTRAP hybrid triple quadrupole/linear ion trap mass spectrometer equipped with a Turbo $\mathrm{V}^{\mathrm{TM}}$ source (AB SCIEX). STX and related congeners were screened using a multiple reaction monitoring (MRM)-based method with the separation of toxins using a TSK-gel Amide-80 column (250 mm $\times 2 \mathrm{~mm}$; Tosoh Bioscience) as described by Dell'Aversano et al. (2005). Two MRM channels for each toxin congener were monitored. Certified toxin standards dcGTX2, dcGTX3, GTX1, GTX2, GTX3, GTX4, GTX5, dcSTX, dcNEO, STX, and NEO (Certified Reference Materials Program, National Research Council, Halifax, Nova Scotia, Canada) were used for toxin analysis. Other PSP toxins without standards (C toxins, dcGTX1, dcGTX4, GTX6, $11[\alpha, \beta]-O H-S T X)$ were also monitored using the MRM channels and with instrumental parameters recommended in Dell'Aversano et al. (2005), since AB SCIEX 4000 QTRAP and API 4000 instruments have almost identical structure in MRM function. The limits of detection for individual toxin standards were in the range of 1 to $20 \mathrm{nM}$ with $5 \mu \mathrm{l}$ injection for the primary MRM channel of each toxin congener. As toxin retention times shifted with the amount of injected extract volume, extracts were diluted to levels (15-fold) in which all sample toxin retention times matched those for reference standards. Samples that were positive for STXs and related congeners by the MRM method were further analyzed using enhanced product ion scan mode to confirm their presence. Only toxins in samples con- firmed by matching product ion spectra with their standards were reported.

\section{RESULTS}

\section{Sturgeon collection and necropsies}

All 3 fish specimens collected for necropsy for the present study were female shortnose sturgeon Acipenser brevirostrum, and were classified as adults based on body length (>50 cm FL) according to published age-length studies (Dadswell et al. 1984, Bain 1997). Specimens Abr070112009, Abr070122009, and Abr070132009 measured 60.5, 63.8, and $56.7 \mathrm{~cm}$ FL and weighed 1.05, 1.47, and $1.19 \mathrm{~kg}$, respectively. Tissues from the fish were in good condition, and the specimens had dark red gill tissue indicating recent death. On gross necropsy, the internal organs were in good condition: the swim bladders were full, the spleens were dark red, the livers were a mottled grey, and these organs had distinct, sharp margins with no signs of discoloration or swelling. No significant traumatic lesions to the head, skin, fins, or tail were observed. A large number of amethyst gem clams Gemma gemma were found in the gut contents of all 3 fish necropsied, an indication of recent feeding. No evidence of infectious disease was found on gross examination. Viral screening performed on kidney and spleen samples detected no infectious pancreatic or hematopoietic necrosis viruses, viral hemorrhagic septicemia virus or infectious salmon anemia virus. Bacterial screening performed on kidney and spleen samples detected no known finfish pathogens (data not shown, J. Pruden pers. comm.).

\section{RBA analyses}

STX-like activity was identified by RBA in all 3 sturgeon specimens analyzed, with concentrations in positive samples ranging between 160 and $576 \mathrm{ng}$ STX-eq. $\mathrm{g}^{-1}$ (Table 1). All 3 stomach content samples tested positive $\left(252,572\right.$, and $576 \mathrm{ng}$ STX-eq. $\left.\mathrm{g}^{-1}\right)$ as well as 2 of 3 liver samples (160 and $204 \mathrm{ng}$ STXeq. $\left.\mathrm{g}^{-1}\right)$. Neither of the gill samples demonstrated STX-like activity.

\section{N2A analyses}

STX-like activity was also detected by N2A in all 3 sturgeon specimens analyzed, with concentrations in 
Table 1. Concentrations of saxitoxin (STX)-like activity detected by neuroblastoma assay (N2A) and receptor-binding assay (RBA) (ng STX-eq. g $^{-1}$ ), and STX congeners (GTX3: gonyautoxin-3) confirmed to be present by liquid chromatography-mass spectrometry (LC-MS) $\left(\mathrm{ng} \mathrm{g}^{-1}\right)$. <dl: below detection limit

\begin{tabular}{|c|c|c|c|c|c|}
\hline \multirow[t]{2}{*}{ Animal ID } & \multirow[t]{2}{*}{ Sample type } & \multirow[t]{2}{*}{$\mathrm{N} 2 \mathrm{~A}$} & \multirow[t]{2}{*}{ RBA } & \multicolumn{2}{|c|}{$-\mathrm{LC}-\mathrm{MS}-$} \\
\hline & & & & STX & GTX3 \\
\hline \multirow[t]{3}{*}{ Abr070112009ME } & Stomach contents & 600 & 576 & 213 & 98 \\
\hline & Liver & $<\mathrm{dl}$ & $<\mathrm{dl}$ & & \\
\hline & Gill & 37 & $<\mathrm{dl}$ & & \\
\hline \multirow[t]{2}{*}{ Abr070122009ME } & Stomach contents & 1500 & 252 & 279 & 70 \\
\hline & Liver & $<\mathrm{dl}$ & 204 & & \\
\hline \multirow[t]{3}{*}{ Abr070132009ME } & Stomach contents & 2300 & 572 & 536 & 207 \\
\hline & Liver & $<\mathrm{dl}$ & 160 & & \\
\hline & Gill & 170 & $<\mathrm{dl}$ & & \\
\hline
\end{tabular}

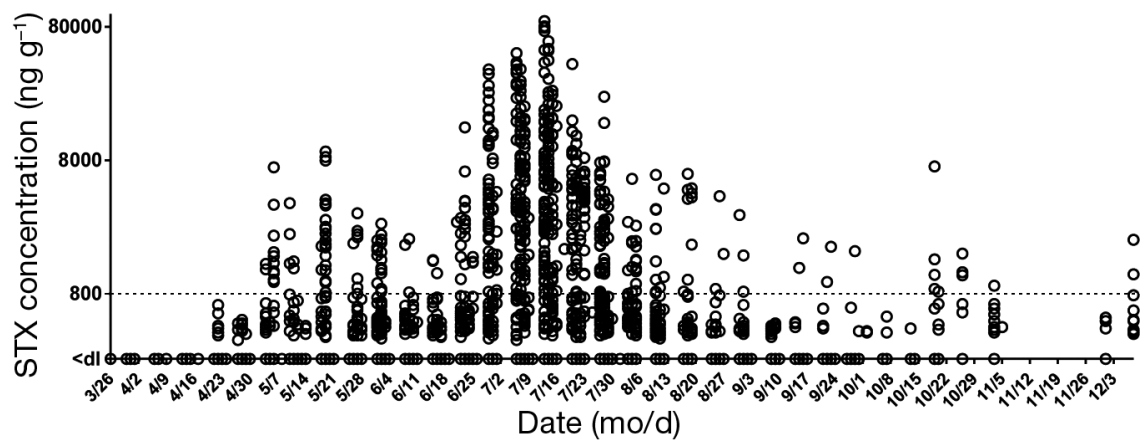

Fig. 1. Shellfish toxicity time series for the state of Maine, USA, during 2009 $(\mathrm{n}=4113)$. Saxitoxin (STX) values are in nanograms per gram of shellfish tissue. Dotted reference line represents $800 \mathrm{ng} \mathrm{g}^{-1}$ federal regulatory limit for STX in seafood. <dl: below limit of detection

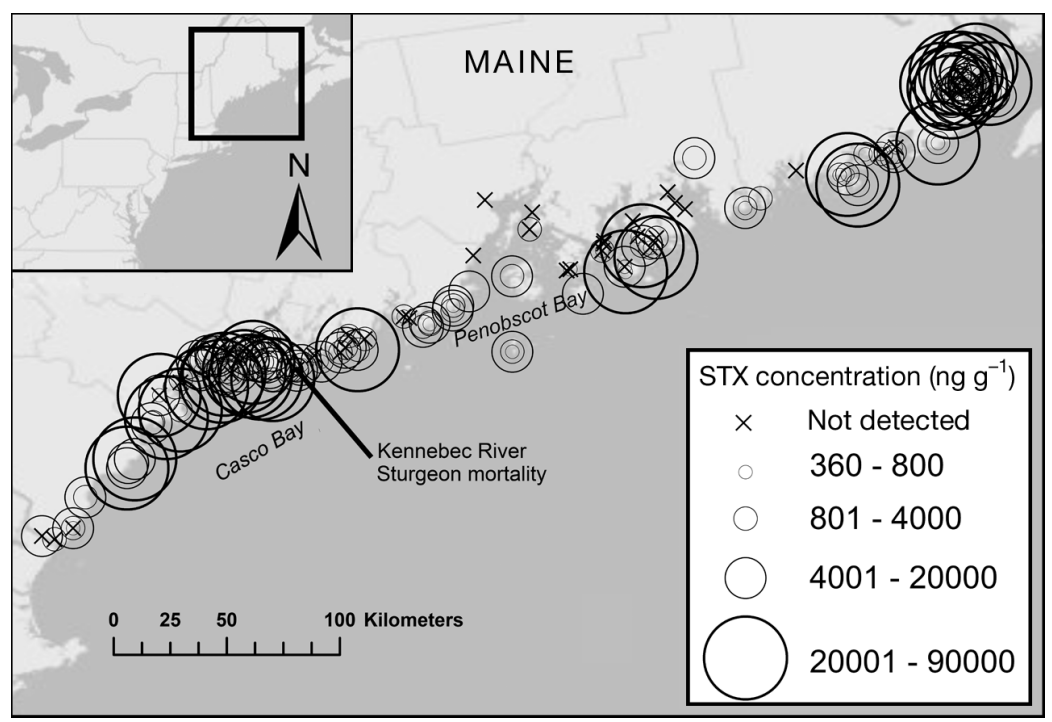

Fig. 2. Spatial distribution of shellfish toxicity values $(n=1229)$ detected in Maine, USA, during the second toxicity peak (25 June to 1 August). Saxitoxin (STX) concentrations expressed in nanograms STX-equivalents per gram of shellfish tissue positive samples ranging between 37 and 2300 ng STX-eq. ${ }^{-1}$ (Table 1). All 3 stomach content samples were positive (600, 1500, and 2300 ng STX-eq. $\mathrm{g}^{-1}$ ), as well as both gill samples (37 and $170 \mathrm{ng}$ STX-eq. $\mathrm{g}^{-1}$ ). None of the liver samples demonstrated STX-like activity.

\section{LC-MS analyses}

Extracts of stomach contents from all 3 sturgeon were analyzed and confirmed positive for the presence of STX and its related congener gonyautoxin-3 (GTX3). Toxin concentrations detected in these samples ranged from 213 to 536 and 70 to $207 \mathrm{ng} \mathrm{g}^{-1}$ of sample for STX and GTX3, respectively (Table 1 ).

\section{Shellfish toxin analyses}

The onset of toxin accumulation in Maine shellfish began in late April, with STX concentrations peaking in mid-May and declining until late June (Fig. 1). By the first week of July, toxin levels detected in shellfish again began to increase, reaching a second toxicity peak on 13 July when concentrations of up to $78000 \mathrm{ng}$ STX-eq. $\mathrm{g}^{-1}$ shellfish tissue were detected in blue mussels from a station in Casco Bay, approximately $\sim 30 \mathrm{~km}$ from the site of the Kennebec River sturgeon mortality event occurring on 10 July (Fig. 2). STX concentrations in blue mussels Mytilus edulis collected during the $3 \mathrm{~d}$ prior to the sturgeon mortalities, and within $\sim 35 \mathrm{~km}$ of the mortality site, exceeded $20000 \mathrm{ng} \mathrm{g}^{-1}$, with a mean concentration of $6400 \mathrm{ng} \mathrm{g}^{-1}$. STX levels in soft-shell clam Mya arenaria and horse mussel Modiolus sp. samples collected from this region and during this time period ( 7 to 9 July) also exceeded $10000 \mathrm{ng} \mathrm{g}^{-1}$. STX concentrations in blue mussels from other stations throughout Maine during the second toxicity peak exceeded 80000 
ng $\mathrm{g}^{-1}$, a value 100 times greater than the USA regulatory limit (800 $\mathrm{ng} \mathrm{g}^{-1}$, or $80 \mu \mathrm{g}$ per $100 \mathrm{~g}$ ) for seafood for human consumption (FDA 2010). Only 3 samples were available from the mouth of the Kennebec River on the day of the sturgeon mortality event, and STX concentrations in soft-shell clam and blue mussels collected at this time and location $\left(43.754787^{\circ} \mathrm{N}\right.$, $69.776231^{\circ} \mathrm{W}$ ) were 1565 (mean) and $2960 \mathrm{ng} \mathrm{g}^{-1}$, respectively. Amethyst gem clams $(\mathrm{n}=1)$ collected on 21 July at the mouth of the Kennebec River, $<1.5 \mathrm{~km}$ from the sturgeon mortality site, had a STX concentration of $450 \mathrm{ng} \mathrm{g}^{-1}$. Overall, STX was detected at various concentrations in 6 species of shellfish collected throughout Maine during the second toxicity peak, data which are summarized in Table 2.

\section{Toxic phytoplankton abundance}

In addition to high levels of shellfish toxicity, extremely dense cell abundances for Alexandrium sp. were also detected throughout the study region. A bloom of A. fundyense was observed throughout Massachusetts, New Hampshire, and Maine, and into the Bay of Fundy (WHOI 2009). Although quantitative cell densities were not recorded for the Kennebec River, surface cell counts from southern Maine during the second toxicity peak were $>1$ million cells $\mathrm{l}^{-1}$, concentrations exceeding the highest density of Alexandrium ever reported for the Gulf of Maine (D. Couture unpubl. data).

\section{DISCUSSION}

Our results demonstrate the temporal and geographical association between a toxic Alexandrium bloom and widespread toxicity of shellfish resources occurring simultaneously with a mortality event of

Table 2. Saxitoxins (STX) detected in various species of Maine shellfish during the second toxicity peak (25 June to 1 August, 2009). Concentrations expressed in nanograms STX-equivalents per gram of shellfish tissue

\begin{tabular}{|c|c|c|c|}
\hline \multirow[t]{2}{*}{ Species } & \multirow[t]{2}{*}{$\mathrm{n}$} & \multicolumn{2}{|c|}{ — STX conc. - } \\
\hline & & Max. & Mean \\
\hline Ocean quahog Arctica islandica & 44 & 7450 & 3065 \\
\hline Amethyst gem clam Gemma gemma & 1 & 450 & 450 \\
\hline Horse mussel Modiolus sp. & 9 & 26560 & 11185 \\
\hline Soft-shell clam Mya arenaria & 395 & 29450 & 1817 \\
\hline Blue mussel Mytilus edulis & 748 & 88450 & 7776 \\
\hline Surf clam Spisula solidissima & 8 & 8340 & 4658 \\
\hline
\end{tabular}

the endangered shortnose sturgeon Acipenser brevirostrum. The presence of high concentrations of Alexandrium cells widely distributed throughout New England coastal waters demonstrates a source of STXs in the water column and in the marine food web. The spatial extent of the Alexandrium bloom was unprecedented, and encompassed the portion of the Kennebec River mouth where the shortnose sturgeon mortalities occurred. The bloom was also present well before these mortalities were reported. The density of this toxic bloom, which reached as high as 1.7 million cells $1^{-1}$ along the Maine coast, was such that it formed a visible red-colored patch of water on the date of the sturgeon mortality (WHOI 2009). State monitoring of commercial shellfish resources, which has long been used as a proxy indicator for the severity of New England HAB events, detected very high levels of STXs in multiple species of bivalve shellfish and reported harvesting closures in virtually all shellfish harvesting sites throughout Maine.

In addition to, and perhaps of greater importance than the association between a toxic bloom and sturgeon mortalities, the present study provides the first report of HAB toxin exposure in this endangered species. Our results demonstrate unequivocal confirmation of oral STX exposure in these animals by LC-MS methods: RBA and N2A analyses detected STX-like activity in sturgeon stomach contents at concentrations of up to $2300 \mathrm{ng} \mathrm{g}^{-1}$ of sample. The stomach contents were also found to contain a large number of bivalves Gemma gemma. This STX concentration represents a level nearly 3 -fold higher than the federal regulatory limit for seafood (800 $\left.\mathrm{ng} \mathrm{g}^{-1}\right)$, and we speculate it may have been a toxic dose to the sturgeon. While the actual concentrations of STX confirmed in stomach contents by LC-MS analyses were lower $\left(<800 \mathrm{ng} \mathrm{g}^{-1}\right)$, the effects of multiple feeding bouts at this concentration over the course of several days are unknown, and may have resulted in chronic, rather than acute exposure in the sturgeon. Although the STX concentrations reported for liver and gill samples differed depending on the detection method used, this likely reflects differences in the type of assay used (whole-cell cytotoxicity vs. receptor-ligand binding), as well as the proximity of the detected values to the detection limits of the N2A and RBA and differences in the degree of sample dilutions required by each assay to eliminate interference from matrix effects. It may also be due to the effect of the toxin profile (i.e. the number and proportion of the various STX congeners) present in the extracts having high toxic activity relative to their 
affinity for the sodium channel receptors, although a systematic comparison of cytotoxic activity for each of the STX congeners by N2A has not yet been performed.

Based on body mass $(1.47,1.05$, and $1.19 \mathrm{~kg})$, STXLC-MS concentrations detected in stomach contents $\left(349,311\right.$, and $\left.743 \mathrm{ng} \mathrm{g}^{-1}\right)$, and minimum volume of stomach contents $(20 \mathrm{ml})$ collected from each sturgeon, we estimate minimum STX doses of 4.7, 5.9, and $12.5 \mu \mathrm{g} \mathrm{STX} \mathrm{kg}{ }^{-1}$ body weight (bw; mean = 7.7) for the 3 fish analyzed in our study. Estimated doses based on RBA analyses were similar (3.4, 9.6, and $11.0 \mu \mathrm{g} \mathrm{STX} \mathrm{kg}{ }^{-1} \mathrm{bw}_{\text {; }}$ mean $=8.0$ ), and estimates based on N2A data were somewhat greater (11.4,

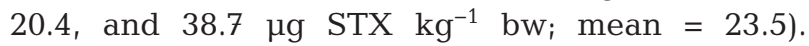
Regardless of the detection method used, these values are much lower than reported oral LD50 doses for experimentally dosed fish (Atlantic herring, American pollock, winter flounder, Atlantic salmon, and cod), which range between 400 and $750 \mu \mathrm{g}$ STX $\mathrm{kg}^{-1}$ bw (White 1981). Our results are more similar to the lower range of estimated STX doses (23 to $970 \mu \mathrm{g}$ $\mathrm{kg}^{-1} \mathrm{bw}$ ) reported for field-exposed fish (sand lance, menhaden, and herring) collected during Alexandrium-associated fish kills (White 1984). While our reported estimates are minimum calculated doses, several factors should be noted that would hypothetically increase the estimated dose of the sturgeon to values more similar to known lethal doses, namely: (1) the stomach contents collected were actually a mixture of ingested material and sturgeon gastric fluid and are thus a 'dilution' of the original ingested STX concentration; (2) the sturgeon stomach contents may not be representative of the material that had already passed through and been absorbed by the intestinal tract, which may have contained a higher STX dose; and (3) a free-ranging fish would be accumulating STX over several feeding bouts (or continuous feeding), instead of through a single meal, and may have a total effective dose much higher than what was detected in single-dose sampling of stomach contents.

Unfortunately, as is common for reports of HAB-associated wildlife mortalities, necropsy findings were insufficient to confirm STX as the proximate cause of death in the sturgeon included in the present study. However, shortnose sturgeon are known to feed heavily on bivalves, filter-feeding organisms that are well-known for their ability to concentrate HAB toxins in the water column and make them available to higher trophic levels (Dadswell et al. 1984, Doucette et al. 2006b). In fact, a large number of amethyst gem clams Gemma gemma were found in all of the stur- geon recovered for necropsy from this mortality event, and tissues from this same shellfish species were shown to contain detectable levels of toxins during the second peak of shellfish toxicity. This is consistent with known feeding habits for adult shortnose sturgeon $(>50 \mathrm{~cm} \mathrm{FL}$ ) and for the size range ( 56.7 to $63.8 \mathrm{~cm} \mathrm{FL)} \mathrm{of} \mathrm{the} 3$ specimens included in the present study (Dadswell et al. 1984). It is unclear whether the sturgeon were also feeding on the more toxic Mytilus edulis and Mya arenaria prior to the mortality event, or if their feeding habits incorporate these species as a normal part of their diet. Future work investigating impacts of New England red tide on shortnose sturgeon should include these 2 shellfish species as potential vectors for trophic transfer of PSP toxins. Our analytical results, combined with the concomitant detection of a toxic $\mathrm{HAB}$ and PSP outbreak, provide evidence for the role of phycotoxins (likely via a bivalve shellfish vector) as a potential contributor to mortality in these animals.

Wildlife mortalities due to STX exposure have been reported previously in New England waters; an unusual mortality event in 1987 involving humpback whales off Cape Cod was attributed to consumption of plankton-feeding Atlantic mackerel Scomber scombrus containing saxitoxin (80 ng STX-eq. $\mathrm{g}^{-1}$ whole fish) (Geraci et al. 1989). During a subsequent humpback whale mortality event occurring on Georges Bank in the Gulf of Maine in August 2003, samples of feces from a dead whale were positive for STX activity (F. Van Dolah \& T. Leighfield unpubl. data). Atlantic herring Clupea harengus harengus kills occurring in the Bay of Fundy in 1976 and 1979 were found to be caused by exposure to STXs ( 14 000 and 640 to 2450 ng STX-eq. ${ }^{-1}$ stomach contents, respectively) produced by Alexandrium sp. (White 1977, 1980). Large die-offs of common terns Sterna hirundo occurring on Monomoy Island, Massachusetts, in 1978 (Nisbet 1983) and in 2005 (T. Leighfield unpubl. data) have also been attributed to STX exposure via consumption of contaminated prey items. In addition, since HAB toxins are commonly distributed throughout marine food webs during a bloom, HAB-related wildlife mortalities often simultaneously affect multiple species (Landsberg 2002). In fact, a common eider Somateria mollissima mortality event occurring near Cape Elizabeth, Maine, was observed $3 \mathrm{~d}$ after the sturgeon mortality described in the present study, in which gastric and intestinal contents collected from these birds were also confirmed to be positive for STX (>500 $\mathrm{ng} \mathrm{g}^{-1}$; S. Fire unpubl. data). The similarity between the STX concentration ranges reported above for previous 
wildlife mortality events and the STX values reported here (252 to $2300 \mathrm{ng} \mathrm{g}^{-1}$ ) suggest that sturgeon from the present study may have been exposed to lethal doses of STX. However, since experimental STX dosing of finfish has shown substantial variability in neurological effects between species, as well as between different age classes of the same species (Lefebvre et al. 2005), additional exposure data are required before confident predictions can be made about the role of STX in this sturgeon mortality event.

Although this is the first reported shortnose sturgeon mortality event associated with a $\mathrm{HAB}$, the timing and location of their foraging activities suggest this endangered species may be repeatedly exposed to STX via their food web. Seasonal Alexandrium blooms and/or associated PSP toxicity outbreaks on the coasts of Maine, New Hampshire, and Massachusetts have occurred virtually every year since 1972, and typically occur between June and August (Anderson 1997). This period coincides with the shortnose sturgeon feeding season, when they utilize estuarine and bay habitats during the summer and early autumn (May to October) for foraging (Dadswell et al. 1984). Furthermore, shortnose sturgeon in Maine are also known to utilize fully saline coastal habitats during the May to July season, including the Kennebec River where the mortality event presented here occurred (Fernandes et al. 2010). This spatial and temporal overlap may pose a significant threat to shortnose sturgeon populations inhabiting these waters.

HAB toxins can often manifest their negative impacts on marine wildlife through dramatic and conspicuous events like mass mortalities, but chronic and sub-lethal effects have also been proposed to play a significant ecological role in various protected marine species (Durbin et al. 2002, Brodie et al. 2006, Goldstein et al. 2008). For example, North Atlantic right whales inhabiting the Bay of Fundy and nearby waters have experienced a decline in reproductive success in recent years; this decline is suspected to be related to chronic exposure to toxins produced during Alexandrium blooms in the region. Doucette et al. (2006a) found a significant negative correlation between yearly maximum Alexandrium counts and right whale calving rates, as well as between PSP shellfish toxicity level and calving rates. If similar sub-acute, population-level impacts are in effect in the shortnose sturgeon population, the consequences could be severe for this already depleted species. Given the endangered status of the shortnose sturgeon population inhabiting this region, together with the potential for STX-contaminated bivalve prey acting as toxin vectors to these fish, our study highlights the need for a more systematic investigation of HAB toxin exposure in New England shortnose sturgeon.

Acknowledgements. The authors thank T. Leighfield, J. Lewis, and S. Morton for providing insightful comments during the review of this manuscript. We thank D. Anderson, F. Van Dolah, J. Ramsdell, and G. Doucette for helpful discussions during manuscript preparation. We also thank the staff of the NOAA Shortnose Sturgeon Recovery Program, U.S. Geological Survey and U.S. Fish and Wildlife Service for assistance with sample collection and other logistical support. This publication does not constitute an endorsement of any commercial product or intend to be an opinion beyond scientific or other results obtained by the National Oceanic and Atmospheric Administration (NOAA). No reference shall be made to NOAA, or this publication furnished by NOAA, to any advertising or sales promotion which would indicate or imply that NOAA recommends or endorses any proprietary product mentioned herein, or which has as its purpose an interest to cause the advertised product to be used or purchased because of this publication.

\section{LITERATURE CITED}

Anderson DM (1997) Bloom dynamics of toxic Alexandrium species in the northeastern U.S. Limnol Oceanogr 42: 1009-1022

Anderson DM, White AW (1989) Toxic dinoflagellates and marine mammal mortalities. Tech Rept WHOI-89-36, Woods Hole Oceanographic Institution, Woods Hole, MA, p 1-65

Anderson DM, White AW (1992) Marine biotoxins at the top of the food chain. Oceanus 35:55-61

- Bain MB (1997) Atlantic and shortnose sturgeons of the Hudson River: common and divergent life history attributes. Environ Biol Fishes 48:347-358

> Bricelj VM, Connell L, Konoki K, MacQuarrie SP, Scheuer T, Catterall WA, Trainer VL (2005) Sodium channel mutation leading to saxitoxin resistance in clams increases risk of PSP. Nature 434:763-767

Brodie EC, Gulland FMD, Greig DJ, Hunter M and others (2006) Domoic acid causes reproductive failure in California sea lions (Zalophus californianus). Mar Mamm Sci 22:700-707

> Collins MR, Post WC, Russ DC, Smith TIJ (2002) Habitat use and movements of juvenile shortnose sturgeon in the Savannah River, Georgia-South Carolina. Trans Am Fish Soc 131:975-979

Couture DA (2007) Maine Department of Marine Resources biotoxin program quality assurance plan-April 2007. Maine Dept. of Marine Resources, Botthbay Harbor and Lamoine, ME, p 1-34. Available at: www.maine.gov/ $\mathrm{dmr} / \mathrm{rm} /$ public_health/biotoxinmonitoring.htm (accessed 1 February 2012)

Couture D (2009) Maine red tide disaster relief programFinal progress report, September 1, 2006-August 31, 2009. Grant NA06:NMF4520317, NOAA Fisheries Northeast Region Grant Program, West Boothbay Harbor, ME

Dadswell MJ, Taubert BD, Squiers TS, Marchette D, Buckley J (1984) Synopsis of biological data on shortnose sturgeon, Acipenser brevirostrum LeSueur, 1818. FAO 
(Food and Agriculture Organization of the United Nations) Fisheries Synopsis 140:1-45

- Dechraoui MY, Wang Z, Ramsdell JS (2007) Intrinsic potency of synthetically prepared brevetoxin cysteine metabolites BTX-B2 and desoxyBTX-B2. Toxicon 50: 825-834

> Deeds JR, Landsberg JH, Etheridge SM, Pitcher GC, Longan SW (2008) Non-traditional vectors for paralytic shellfish poisoning. Mar Drugs 6:308-348

> Dell'Aversano C, Hess P, Quilliam MA (2005) Hydrophilic interaction liquid chromatography-mass spectrometry for the analysis of paralytic shellfish poisoning (PSP) toxins. J Chromatogr A 1081:190-201

- Doucette GJ, Logan MM, Ramsdell JS, Van Dolah FM (1997) Development and preliminary validation of a microtiter plate-based receptor binding assay for paralytic shellfish poisoning toxins. Toxicon 35:625-636

> Doucette GJ, Cembella AD, Martin JL, Michaud J, Cole TVN, Rolland RM (2006a) Paralytic shellfish poisoning (PSP) toxins in North Atlantic right whales Eubalaena glacialis and their zooplankton prey in the Bay of Fundy, Canada. Mar Ecol Prog Ser 306:303-313

Doucette G, Maneiro I, Riveiro I, Svensen C (2006b) Phycotoxin pathways in aquatic food webs: transfer, accumulation and degradation. In: Graneli E, Turner JT (eds) Ecology of harmful algae. Springer Verlag, Berlin, p 283-295

> Durbin E, Teegarden G, Campbell R, Cembella A, Baumgartner MF, Mate BR (2002) North Atlantic right whales, Eubalaena glacialis, exposed to paralytic shellfish poisoning (PSP) toxins via a zooplankton vector, Calanus finmarchicus. Harmful Algae 1:243-251

FDA (United States Food and Drug Administration) (2010) FDA \& EPA safety levels in regulations and guidance (Appendix 5). Available at: www.fda.gov/Food/ GuidanceComplianceRegulatoryInformation/GuidanceDocuments/Seafood/FishandFisheriesProductsHazards andControlsGuide/ucm120108.htm (accessed 1 February 2012)

Fernandes SJ, Zydlewski GB, Zydlewski JD, Wippelhauser GS, Kinnison MT (2010) Seasonal distribution and movements of shortnose sturgeon and Atlantic sturgeon in the Penobscot River Estuary, Maine. Trans Am Fish Soc 139: 1436-1449

Geraci JR, Anderson DM, Timperi RJ, St. Aubin DJ, Early GA, Prescott JH, Mayo CA (1989) Humpback whales (Megaptera novaeangliae) fatally poisoned by dinoflagellate toxin. Can J Fish Aquat Sci 46:1895-1898

Goldstein T, Mazet JAK, Zabka TS, Langlois G and others (2008) Novel symptomatology and changing epidemiology of domoic acid toxicosis in California sea lions (Zalophus californianus): an increasing risk to marine mammal health. Proc R Soc Lond B 275:267-276

Hoagland P, Anderson DM, Kaoru Y, White AW (2002) The economic effects of harmful algal blooms in the United States: estimates, assessment issues, and information needs. Estuar Coast 25:819-837

Kirkpatrick B, Fleming LE, Squicciarini D, Backer LC and others (2004) Literature review of Florida red tide: implications for human health effects. Harmful Algae 3:99-115

Kynard B, Horgan M, Kieffer M, Seibel D (2000) Habitats used by shortnose sturgeon in two Massachusetts rivers, with notes on estuarine Atlantic sturgeon: a hierarchical approach. Trans Am Fish Soc 129:487-503
Landsberg JH (2002) The effects of harmful algal blooms on aquatic organisms. Rev Fish Sci 10:113-390

Lefebvre KA, Elder NE, Hershberger PK, Trainer VL, Stehr CM, Scholz NL (2005) Dissolved saxitoxin causes transient inhibition of sensorimotor function in larval Pacific herring (Clupea harengus pallasi). Mar Biol 147: 1393-1402

> Manger RL, Leja LS, Lee SY, Hungerford JM, Wekell MM (1993) Tetrazolium-based cell bioassay for neurotoxins active on voltage-sensitive sodium channels: semiautomated assay for saxitoxins, brevetoxins, and ciguatoxins. Anal Biochem 214:190-194

> McCleave JD, Fried SM, Towt AK (1977) Daily movements of shortnose sturgeon, Acipenser brevirostrum, in a Maine estuary. Copeia 1977:149-157

Moser ML, Ross SW (1995) Habitat use and movements of shortnose and Atlantic sturgeons in the lower Cape Fear River, North Carolina. Trans Am Fish Soc 124: 225-234

Nisbet ICT (1983) Paralytic shellfish poisoning; effects on breeding terns. Condor 85:338-345

NMFS (National Marine Fisheries Service) (1998) Recovery plan for the shortnose sturgeon (Acipenser brevirostrum). Prepared by the Shortnose Sturgeon Recovery Team for the NMFS, Silver Spring, MD

Sasner JJ, Ikawa M, Barrett BE (1975) The 1972 red tide in New Hampshire. In: LoCicero VR (ed) Proceedings of the 1st international conference on toxic dinoflagellate blooms. Massachusetts Science and Technology Foundation, Wakefield, MA, p 517-523

Udall SL (1967) Office of the secretary, native fish and wildlife, endangered species. Fed Regist 32:4001

- Van Dolah FM (2000) Marine algal toxins: origins, health effects, and their increased occurrence. Environ Health Perspect 108:133-141

Van Dolah FM (2005) Effects of harmful algal blooms. In: Reynolds J, Perrin W, Reeves R, Montgomery S, Ragen T (eds) Marine mammal research: conservation beyond crisis. Johns Hopkins University Press, Baltimore, MD, p 85-101

Van Dolah FM, Fire SE, Leighfield TA, Mikulski CM, Doucette GJ (2012) Determination of paralytic shellfish toxins in shellfish by receptor binding assay: a collaborative study. J AOAC Int 95:795-812

White AW (1977) Dinoflagellate toxins as probable cause of an Atlantic herring (Clupea harengus harengus) kill, and pteropods as apparent vector. J Fish Res Board Can 34: 2421-2424

White AW (1980) Recurrence of kills of Atlantic herring (Clupea harengus harengus) caused by dinoflagellate toxins transferred through herbivorous zooplankton. Can J Fish Aquat Sci 37:2262-2265

- White AW (1981) Sensitivity of marine fishes to toxins from the red-tide dinoflagellate Gonyaulax excavata and implications for fish kills. Mar Biol 65:255-260

White AW (1984) Paralytic shellfish toxins and finfish. In: Ragelis EP (ed) Seafood toxins. ACS Symposium Series 262, American Chemical Society, Washington, DC, p 171-180

WHOI (Woods Hole Oceanographic Institute) (2009) Previous outbreaks - July 24, 2009 status report. Northeast PSP-New England harmful algal bloom/red tide information. Available at: www.whoi.edu/page.do?pid= 33475\&tid=282\&cid=74967 (accessed 1 February 2012) 